\title{
POTENSI NANOPARTIKEL ALGINAT- KITOSAN - EKSTRAK DAUN KEDONDONG HUTAN (SPONDIAS PINNATA (L.f.) Kurz.) DALAM PENATALAKSANAAN TUBERKULOSIS DAN MULTI DRUG RESISTANCE TUBERCULOSIS (MDR-TB)
}

\author{
${ }^{1}$ Ni Made Gitari, ${ }^{2}$ I Gusti Ngurah Bagus Rai Mulya Hartawan, ${ }^{3}$ Ida Bagus Nyoman Putra \\ Dwija \\ ${ }^{1,2}$ Jurusan Pendidikan Dokter, FK Universitas Udayana Bali \\ ${ }^{3}$ Departemen Mikrobiologi, FK Universitas Udayana Bali \\ E-mail:gitatarigitari@gmail.com
}

\begin{abstract}
Tuberculosis (TB) is an infectious disease caused by M. tuberculosis resulting in high morbidity and mortality. The outbreak of $M$. tuberculoisis strains resistant to anti-tuberculosis drugs makes TB treatment more difficult and high economic burden. The purpose of this paper is to describe the potential of alginic nanoparticles-chitosan-leaf extracts of kedondong hutan as management of TB and MDR-TB. Of the 87 journals reviewed, 50 journals were found in accordance with the topic of discussion and used as reference of this paper. The alginate-chitosan-leaf extract kedondong hutan nanoparticles can inhibits the synthesis of mycolic acid $M$. tuberculosis, proteasom and resulting lysis of M. tuberculosis cell wall. The combination of alginate-chitosan coating is the most appropriate combination because it can increase the bioavailability and sustained release of antibacterial drugs. The leaf extract of kedondong hutan contains flavonoid and triterpenoid compounds that function as antituberculosis. Flavonoids can bind to the active site HadB thus inhibiting the activity of $\beta$ hydroxyacyl-ACP dehydratase that functions in meromycolic chain elongation. In addition, flavonoids can inhibits the proteasome of $M$. tuberculosis in dormant state. Triterpenoids have clusters that are capable of causing lysis cell walls of $M$. tuberculsosis. The alginate-chitosan-leaf extract kedondong hutan nanoparticles have potential as new therapies for TB and MDR-TB. There has been no research on the combination of these modalities so that further research is needed to find out the exact potential of alginate nanoparticles-chitosan-leaf extract of kedondodong hutan.
\end{abstract}

\begin{abstract}
Abstrak. Tuberkulosis (TB) merupakan penyakit infeksi akibat M.tuberculosis yang mengakibatkan morbiditas dan mortalitas yang tinggi. Merebaknya strain M. tuberculoisis yang resisten terhadap obat anti tuberkulosis membuat penanganan TB menjadi semakin sulit dan beban ekonomi yang tinggi. Tujuan dari penulisan paper gagasan tulis ini untuk mendeskripsikan potensi nanopartikel alginat-kitosan-ekstrak daun kedondong hutan sebagai penatalaksanaan TB dan MDR-TB. Dari 87 jurnal yang ditelaah, 50 jurnal ditemukan sesuai dengan topik bahasan dan digunakan sebagai referensi karya ini. Kombinasi penyalutan alginat-kitosan merupakan kombinasi yang paling tepat karena dapat meningkatkan bioavailabilitas dan pelepasan berkelanjutan dari obat antibakteri. Nanopartikel alginat-kitosan-ekstrak daun kedondong hutan dapat menghambat sintesis asam mikolat M. tuberculosis, proteasom dan mengakibatkan lisis dinding sel M. tuberculosis. Ekstrak daun kedondong hutan mengandung senyawa flavonoid dan triterpenoid yang berfungsi sebagai antituberkulosis. Flavonoid dapat berikatan dengan situs aktif HadB sehingga menghambat aktivitas enzim $\beta$-hydroxyacyl-ACP dehydratase yang berfungsi dalam elongasi rantai meromycolic. Selain itu, flavonoid dapat menghambat proteasom M. tuberculosis yang dalam keadaan dorman. Triterpenoid memiliki gugus sehingga mampu mengakibatkan lisis dinding sel M. tuberculsosis. Nanopartikel alginat-kitosan-ekstrak daun kedondong hutan memiliki potensi sebagai terapi baru untuk TB dan MDR-TB. Belum terdapat penelitian mengenai kombinasi modalitas ini sehingga diperlukan penelitian lebih lanjut untuk mengetahui potensi pasti nanopartikel alginatkitosan-ekstrak daun kedondong hutan.
\end{abstract}

Kata Kunci: Tuberkulosis, Daun Kedondong Hutan (Spondias pinnata (L.f.) Kurz), Nanopartikel Alginat, Nanopartikel Kitosan, Asam Mikolat

Tuberkulosis (TB) merupakan salah satu penyakit infeksi yang menjadi permasalahan kesehatan di seluruh dunia. Infeksi TB disebabkan oleh bakteri Mycobacterium tuberculosis (M. tuberculosis) yang ditularkan melalui droplet penderita TB. Munculnya multi 
drug resistant tuberculosis (MDR-TB) dan koinfeksi HIV menyebabkan kesulitan besar dalam penanganan TB (Faso dkk. 2009, Cantaloube dkk. 2011, Dong dkk. 2015). MDRTB merupakan $M$. tuberculosis yang resistan terhadap dua obat anti tuberkulosis (OAT) lini pertama yang paling poten yaitu isoniazid dan rifampisin (Lin, 2014, Dong dkk. 2015). Berdasarkan data World Health Organization (WHO), pada tahun 2014 di seluruh dunia terdapat 9,6 juta kasus TB dengan 1,5 juta kasus kematian, 5\% dari total kasus TB merupakan MDR-TB. Indonesia menyumbang $10 \%$ dari total kasus TB di seluruh dunia pada tahun 2014 (WHO, 2015). Pengobatan yang tidak memadai atau tidak lengkap, kepatuhan pengobatan yang buruk akibat tingginya efek samping dan lamanya durasi pengobatan TB menyebabkan munculnya resistensi terhadap OAT baik dalam bentuk MDR-TB maupun extensively drug resistant tuberculosis (XDR-TB) (Skrahina dkk. 2013).

OAT lini pertama yaitu rifampisin dapat berinteraksi dengan antiretroviral sehingga dapat menghambat pengobatan TB yang disertai koinfeksi dengan HIV (Ginsberg, 2010). Penanganan MDR-TB memerlukan kombinasi tiga sampai lima OAT lini kedua sehingga pengobatan menjadi lebih mahal dan menimbulkan banyak efek samping (Long \& Langlois-klassen 2013). Selain itu, beberapa OAT lini kedua diadministrasikan secara parenteral dan memerlukan waktu pengobatan 18-24 bulan sehingga mengakibatkan beban ekonomi 10-100 kali lebih tinggi daripada TB non MDR (Europe, 2008, Faso dkk. 2009, Ding dkk. 2017). Hal ini memicu penelitian untuk menemukan obat anti-tuberkulosis yang lebih baru sebagai penatalaksanaan TB baik yang MDR maupun TB non-MDR. Selain itu, diperlukan untuk mengembangkan OAT dengan minimal efek samping, lebih efektif dan terjangkau serta dapat bekerja dalam periode waktu yang lebih singkat.

Asam mikolat merupakan unsur utama dinding sel $M$. tuberculosis sehingga jalur biosintesis asam mikolat merupakan target yang menjanjikan untuk pengembangan antibiotik yang efisien (Cantaloube dkk. 2011, Dong dkk. 2015). Sintesis asam mikolat melibatkan dua tipe fatty acid-synthase system (FAS) yaitu FAS-I dan FAS-II. FAS-II terdiri dari serangkaian enzim yang berfungsi untuk elongasi rantai asam lemak yang disintesis oleh FAS-I. Inaktivasi atau defisiensi salah satu enzim akan menghambat biosintesis asam mikolat, sehingga merupakan salah satu target potensial dalam pengembangan OAT (Dong dkk. 2015).

Daun kedondong hutan memiliki nama latin Spondias pinnata (L.f.) Kurz, secara tradisional telah digunakan sebagai obat disentri dan batuk (Gupta dkk. 2010, Jain dkk. 2014, Mag dkk. 2015). Ekstrak daun kedondong hutan memiliki kandungan flavonoid, steroid dan triterpenoid (Kunwar dkk. 2010, Trisnawati dkk. 2011, Labu dkk. 2015, Uddin dkk. 2016). Kandungan flavonoid dan triterpenoid ekstrak kedondong hutan berkontribusi pada aktivitasnya sebagai antituberkulosis. Flavonoid mampu menghambat sintesis asam mikolat dengan menghambat aktivitas enzim $\beta$ hydroxyacyl-ACP dehydratase dan proteasom M.tuberculosis. (Dong dkk. 2015). Sementara triterpenoid dapat mengakibatkan lisis dinding sel bakteri (Jimenez-Arellanes dkk. 2007).

Nanopartikel merupakan dispersi partikulat atau partikel koloid dengan ukuran submikron $(<1 \quad$ um). Penghantaran obat menggunakan polimer alami seperti alginat dan kitosan memberikan banyak keuntungan seperti meningkatkan stabilitas obat, meningkatkan bioavaibilitas obat sehingga mengurangi frekuensi dosis (Lu dkk. 2014, Nasirudin dkk. 2017). Selain itu polimer alami khususnya polisakarida tersedia melimpah di alam dan membutuhkan biaya relatif murah pada proses pembuatannya (Liu dkk. 2008, Sosnik dkk. 2010, Ikram \& Ahmed 2017, Nasirudin dkk. 2017). Alginat merupakan polisakarida linear, tidak bercabang yang mengandung rantai dari asam mannuronat dan asam guluronat. 
Karakteristik nanopartikel alginat yang mendukung sebagai penghantar obat yang ideal yaitu permukaan yang mudah melekat dengan epitel usus, proses enkapsulasi obat tanpa perlu menggunakan pelarut organik, sifat penyerapan yang tinggi, kapasitas untuk mengontrol penyerapan tersebut dengan mekanisme easycoating measures dan tidak toksik (Nasirudin dkk. 2017).

Kitosan adalah suatu polisakarida linear yang diperoleh dari deasetilasi kitin. Kitin banyak ditemukan pada cangkang Crustaceae sp seperti udang, kepiting, lobster, sehingga menempati urutan kedua polisakarida dalam hal ketersediaannya di alam (Rudzinki \& Aminabhavi 2010, Ngo dkk. 2015). Nanopartikel kitosan memiliki karakteristik seperti biokompatibel yang tinggi, hipoalergenik, bakteriostatis, murah, mudah disintesis dan tidak toksik. Selain itu nanopartikel kitosan dapat dijadikan matriks untuk berbagai jenis obat dan ekstrak tanaman serta stabil selama penggunaan (Lee dkk. 2011, Zhang dkk. 2016). Formulasi nanopatikel obat antituberkulosis dengan kitosan terbukti tidak toksik dan aktivitasnya lebih tinggi dalam mereduksi $M$. tuberculosis dibandingkan obat anti-tuberkulosis tanpa kitosan (Garg dkk. 2015). Bentuk kompleks poli-ionik alginatkitosan melindungi ekstrak yang dienkapsulasi, bersifat biokompatibel, biodegradable, dan membatasi pelepasan obat atau senyawa yang dienkapsulasi menjadi lebih efektif dibandingkan pemakaian alginat dan kitosan secara terpisah.

Berdasarkan pemaparan data-data dan fakta di atas nanopartikel alginat-kitosan-ekstrak daun kedondong hutan dapat berpotensi sebagai terapi dalam penatalaksanaan TB dan MDR-TB sehingga diperlukan pembahasan lebih mendalam mengenai modalitas ini. Tujuan dari penulisan paper gagasan tulis ini yaitu untuk mendeskripsikan potensi nanopartikel alginatkitosan-ekstrak daun kedondong hutan dalam penatalaksanaan TB dan MDR-TB, sehingga diharapkan nanopartikel alginat-kitosan-ekstrak daun kedondong hutan dapat diaplikasikan sebagai terapi TB dan MDR-TB di masa depan.

\section{METODE PENULISAN}

Penulisan karya ilmiah gagasan tertulis ini menggunakan metode studi pustaka yang didasarkan atas hasil studi terhadap berbagai literatur yang telah teruji validitasnya, berhubungan satu sama lain, serta mendukung uraian atau analisis pembahasan. Studi pustaka menggunakan database www.proquest.com, www.pubmed.com dan scholar.google.com dengan menggunakan kata kunci "Tuberkulosis, Daun Kedondong Hutan (Spondias pinnata (L.f.) Kurz), Nanopartikel Alginat, Nanopartikel Kitosan dan Asam Mikolat". Metode studi pustaka hanya diperuntukkan kepada jurnal ilmiah yang menggunakan Bahasa Inggris, Bahasa Indonesia, memiliki abstrak.

Literatur yang didapat akan menjalani proses pemindaian untuk mengeksklusi jurnal ilmiah yang bersifat tidak relevan terhadap "Tuberkulosis, Daun Kedondong Hutan (Spondias pinnata (L.f.) Kurz), Nanopartikel Alginat, nanopartikel Kitosan dan Asam Mikolat". Terdapat 87 artikel atau jurnal ilmiah yang sesuai dengan topik yang dibahas, namun hanya 50 jurnal atau publikasi yang memenuhi kriteria inklusi yang telah ditetapkan oleh penulis.

\section{HASIL DAN PEMBAHASAN}

\section{Patofisiologi TB dan Sintesis Asam mikolat}

Infeksi TB dapat ditularkan dari droplet yang mengandung bakteri $M$. tuberculosis yang kemudian dihirup oleh orang lain saat seseorang dengan infeksi TB batuk, bersin, atau selama pembicaraan. Hanya sekitar $10 \%$ orang yang terinfeksi mengembangkan penyakit TB aktif selama masa hidupnya (Zhang, 2008). M. tuberculosis yang menginfeksi paru-paru akan mengaktifkan fibroblas, makrofag dan sel dendritik. Makrofag akan memfagositosis M.tuberculsois dan mengeluarkan sitokin proinflamasi yang akan mengaktifkan sel-sel imun lainnya (Jeon dkk. 2017). Jika makrofag tidak 
mampu mencerna bakteri maka $M$. tuberculosis akan bereplikasi dalam makrofag dan membentuk koloni di paru-paru yang dikenal dengan fokus primer (Bauman, 2012). Terjadinya MDR-TB dapat diakibatkan oleh mutasi pada gen katG, inhA, kasA, and ahpC, yang menimbulkan resistensi terhadap isoniazid dan mutasi pada gen rpoB yang menyebabkan resistensi terhadap rifampisin (Macedo dkk. 2008, Ahmad \& Mokaddas 2009)

Asam mikolat merupakan komponen lipid utama yang paling spesifik dari dinding sel M. tuberculosis dan merupakan barrier fisiologis antara bakteri dengan lingkungannya (Brown dkk. 2017). FAS-II terdiri dari enzimenzim yang berfungsi dalam elongasi asam lemak yang telah disintesis FAS-I yaitu $\beta$ ketoacyl-ACP synthetase (KasA dan KasB), $\beta$ ketoacyl-ACP reductase (MabA), $\beta$ hydroxyacyl-ACP dehydratase (HadABC), dan trans-2-enoyl-ACP reductase (InhA) (Belardinelli, 2013). Substrat awal FAS-II untuk sintesis rantai meromycolic yaitu keto-acyl-ACP yang merupakan hasil dari kondensasi oleh protein $\mathrm{mtFabH}$ acyl $\mathrm{CoA}$ yang dihasilkan dari FAS-I dengan malonyl-ACP yang dihasilkan oleh malonyl CoA ACP transacylase (MCAT) mtFabD. Selanjutnya terjadi reduksi oleh $\beta$ ketoacyl-ACP reductase, lalu terjadi dehidrasi oleh $\beta$-hydroxyacyl-ACP dehydratase dan reduksi oleh trans-2-enoyl-ACP reductase. Rantai acyl jenuh masuk ke dalam siklus elongasi baru melalui kondensasi oleh $\beta$ ketoacyl-ACP synthetase (KasA atau KasB) dengan unit malonyl-ACP baru. Rantai meromycolic dimodifikasi pada posisi distal (D) dan proksimal $(\mathrm{P})$. Setelah sintesisnya, rantai meromycolic disekuilasi dan diligasi oleh FadD32 ke Pks13, yang merupakan enzim kondensasi terminal yang menghubungkan rantai meromycolic dengan rantai alpha karboksilat yang berasal dari FAS-I (Cantaloube dkk. 2011).

Enzim $\beta$-hydroxyacyl-ACP dehydratase membentuk kompleks tersusun oleh heterodimer HadAB dan HadBC yang dikodekan dalam satu operon (hadABC). Berdasarkan penelitian Jakson dkk, tidak ditemukan mutasi pada hadB (Belardinelli, 2013). Struktur MtbHadAB complex terdiri dari double hotdog fold dan hanya terdapat satu situs aktif dalam heterodimer interface. Selama katalisis, kompleks MtbHadAB mengikat AcpM dan asam lemak. Substrat asam lemak mengikat dalam saluran sempit yang terbentuk di tempat HadA bertemu dengan HadB (Belardinelli, 2013).

Mekanisme Konstruksi dan Administrasi Nanopartikel Alginat-Kitosan-Ekstrak Daun Kedondong Hutan

Ekstraksi daun kedondong didapat dengan cara ekstrak etanol. Daun kedondong hutan yang sudah kering dan bersih diolah menggunakan penggilingan skala laboratorium dan blender. Satu kilogram sampel kering daun kedondong hutan diekstraksi dengan metode maserasi menggunakan 14,6 L pelarut etanol $80 \%$ pada suhu $50^{\circ} \mathrm{C}$. Maserat diendapkan semalam, disaring dan pelarut diuapkan dengan vacuum rotary evaporator pada suhu $50^{\circ} \mathrm{C}$ (Silva dkk. 2012). Selanjutnya dilakukan fraksinasi untuk memperoleh senyawa flavonoid dan triterpenoid. Flavonoid dan triterpenoid ekstrak daun kedondong hutan selanjutnya suspensikan/dilarutkan dengan akuades deionisasi dan diaduk dengan magnetic stirer pada suhu kamar $\left(25^{\circ} \mathrm{C}\right)$ hingga larut. Kitosan $100 \mathrm{~mL}$ (bubuk kitosan dilarutkan dalam dalam $1 \%$ asam asetat glasial) dan diteteskan $350 \mathrm{~mL}$ larutan NaTPP sedikit demi sedikit sambil tetap diaduk sehingga terbentuk suspensi nanopartikel (Iswanda dkk. 2013). Berdasarkan penelitian Dustgania Amir dkk. (2008), nanopartikel yang dibuat dengan metode gelasi ionik dengan komposisi kitosan dan natrium tripolifosfat menghasilkan nanopartikel dengan ukuran 250$350 \mathrm{~nm}$ dengan efisiensi penyerapan zat aktif sebesar $72,2 \%$.

Dalam rangka mengkombinasikan dengan nanopartikel kitosan, nanopartikel alginat disiapkan dengan metode koaservasi (Vandamme dkk. 2007). Larutan natrium alginat dimasukan melalui jarum berlubang kecil ke 
dalam larutan dari agen kationik, seperti ion kalsium, kitosan atau poly-L-lysine kation crosslink dengan asam guluronat dan asam manuronat untuk membentuk struktur egg-box atau pre-gel yang membentuk inti dari matriks gel. Setelah itu, dilakukan penambahan larutan hasil gelasi ionik dari kitosan-ekstrak daun kedondong hutan untuk membentuk suatu lapisan kompleks polielektrolit dan terbentuklah nanopartikel alginat-kitosan-ekstrak daun kedondong hutan (De \& Robinson 2003, Honary dkk. 2009). Pembuatan bubuk nanopartikel alginat-kitosanekstrak daun kedondong hutan dipreparasi dengan metode pengeringan semprot (spray drying) (Morgen dkk. 2012).

Nanopartikel alginat-kitosan-ekstrak daun kedondong hutan diadministrasikan secara oral. Enkapsulasi dengan nanopartikel alginatkitosan akan meningkatkan absopsi obat di mukosa usus. Studi penggunaan nanopartikel alginat-kitosan dikombinasikan dengan ekstrak Piper sarmentosum yang tinggi flavonoid dengan efisiensi permuatan lebih dari $97 \%$ dan waktu pelepasan bahan aktif secara berkelanjutan selama 10 jam (Chan dkk. 2010). Formulasi alginat-kitosan mengalokasikan lebih banyak pemuatan obat dengan konsumsi polimer yang kecil dan memberikan pelepasan berkelanjutan untuk 7-11 hari dalam plasma dan 15 hari di organ hanya dengan setelah satu dosis oral (Srivastava \& Satyanarayana 2007).

Potensi Penghambatan M.tuberculosis oleh Nanopartikel Alginat-Kitosan-Ekstrak Daun Kedondong Hutan (Flavonoid dan Triterpenoid)

Spesies Spondias mengandung triterpenoid yaitu asam oleanolat dan flavonoid seperti kuersetin, kaempferol, kaempferida dan rhamnetin (Silva dkk. 2012). Ekstrak flavonoid daun kedondong hutan memiliki efek menghambat enzim $\beta$-hidroksyacyl-ACP dehydratase pada FAS-II dengan berikatan pada situs aktif HadB (Gambar 1) (Zhang, 2008). Hal ini akan mengakibatkan terganggunya sintesis asam mikolat sehingga mengganggu pertumbuhan $M$. tuberculosis. Flavonoid yang menargetkan HadB terbukti dapat mengganggu biosintesis asam lemak, sehingga menghambat pertumbuhan Mycobacterium bovis BCG secara efektif (Dong dkk. 2015).

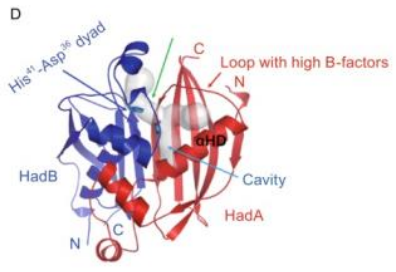

Gambar 1. Tempat Berikatan Flavonoid pada Situs Aktif HadB (Warna Abu-Abu). ${ }^{[3]}$

Senyawa triterpenoid dapat berpenetrasi melewati dinding sel $M$. tuberculosis yang kaya akan lipid karena bersifat semi polar hingga non polar. Triterpenoid memiliki subtituen hidroksil atau keto pada cincin A atau B dan subtituen karboksil pada cincin D atau E pada struktur inti pentasikliknya sehingga mampu melisiskan dinding sel M. tuberculosis (Jimenez-Arellanes dkk. 2007). Triterpenoid dengan konsentrasi 64 $\mu \mathrm{g} / \mathrm{ml}$ memiliki potensi hambatan terhadap $M$. tuberculosis sebesar 92.8\% (Olugbuyiro dkk. 2009). Selain itu, Adelina dkk. menemukan bahwa asam oleanolat memiliki nilai minimum inhibitory concentration (MIC) terhadap $M$. tuberculosis H37Rv sebesar $25 \mu \mathrm{g} / \mathrm{ml}$ (Jim dkk. 2007). Selain itu, studi yang dilakukan Lopez dkk. (2015) menunjukkan bahwa asam oleanolat pada konsentrasi 2,5 dan $0,625 \mu \mathrm{g} / \mathrm{mL}$ menyebabkan penurunan intracellular colony forming unit (CFU) dari $10^{4}$ menjadi $10^{1} / \mathrm{mL}$. Berdasarkan studi secara in vitro, ekstrak metanol daun kedondong hutan pada konsentrasi 50 dan $250 \mathrm{mg} / \mathrm{mL}$ secara efektif mampu menghambat pertumbuhan strain MDR-TB dengan presentase hambatan hingga $100 \%$ (Silva dkk. 2012). Studi lain menunjukkan ekstrak n-heksana daun kedondong hutan sebesar $50 \mathrm{mg} / \mathrm{mL}$ mampu menghambat pertumbuhan strain MDR-TB dengan presentase hambatan pada pengamatan minggu ke-6 sebesar 91,67\% (Savitri \& Ariantari 2013). 
Proteasom M. tuberculosis mengakibatkan bakteri tahan terhadap kerusakan oleh reactive oxygen dan nitrogen intermediate (ROI/RNI) serta pada lingkungan yang asam di dalam makrofag sehingga berperan penting dalam virulensi bakteri. Selain itu, proteasom berperan untuk remove protein yang rusak akibat ROI atau RNI serta berperan untuk menurunkan faktor transkripsi yang mengatur ekspresi gen yang melawan pertahanan inang sehingga proteasom M.tuberculosis telah ditetapkan sebagai target yang tepat untuk pengembangan agen anti-TB (Zheng dkk. 2014). Kemferol dan kuersetin memiliki aktivitas sebagai proteasom inhibitor M.tuberculosis dengan nilai inhibitory activity masing-masing sebesar $74,40 \%$ dan $68,29 \%$. Selain itu, kuersetin dan kaemferol $(200 \mu \mathrm{m})$ memiliki nilai IC50 masing-masing sebesar 71,29 $\mu \mathrm{M}$ dan

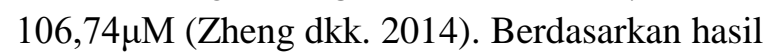
penelitian tersebut, maka flavonoid yang didapat dari ekstrak daun kedondong hutan berpotensi untuk mengatasi infeksi M. tuberculosis yang tidak bereplikasi.

Ekstrak etanol $80 \%$ daun kedondong hutan terbukti tidak bersifat toksik (Purwani dkk. 2013). Potensi nanopartikel alginat-kitosanekstrak daun kedondong hutan memiliki keunggulan sebagai bahan alami yang banyak ditemukan di Indonesia. Pemanfaatan bioaktivitas alginat, kitosan dan ekstrak daun kedondong hutan secara maksimal dapat meningkatkan potensi alam dan kekayaan hayati di Indonesia. Meskipun sampai saat ini belum ditemukan adanya mutasi pada HadB tetapi mutasi pada hadABC diduga dapat mengakibatkan resistensi terhadap modalitas ini sehingga perlu dikombinasikan dengan OAT jenis lainnya untuk mempercepat durasi pengobatan.

\section{KESIMPULAN}

Berdasarkan hasil kajian literatur, nanopartikel alginat-kitosan-ekstrak kedondong hutan berpotensi untuk diaplikasikan sebagai terapi pada penatalaksanaan Tb dan MDR-TB.
Flavonoid dari ekstrak daun kedondong hutan mampu berikatan dengan HadB sehingga akan menghambat enzim $\beta$-hydroxyacyl-ACP dehydratase dan mampu menghambat proteasom M. tuberculosis.. Selain itu, kandungan triterpenoid dapat menyebabkan lisis dinding sel M. tuberculosis. Nanopartikel alginat-kitosanekstrak etanol daun kedondong hutan berasal dari bahan alami, mudah diperoleh dan tidak memiliki efek toksik sebagai penatalaksanaan TB dan MDR-TB. Diharapkan modalitas ini dapat mengurangi morbiditas maupun mortalitas yang diakibatkan oleh infeksi M. tuberculosis baik yang resisten maupun yang sensitif. Dengan demikian, nanopartikel alginat-kitosanekstrak etanol daun kedondong hutan dapat menjadi penatalaksanaan TB dan MDR-TB di masa depan.

\section{DAFTAR PUSTAKA}

Ahmad S, Mokaddas E. 2009. Recent advances in the diagnosis and treatment of multidrug-resistant tuberculosis. Respir Med [Internet]. Elsevier Ltd; 103(12):1777-90. Tersedia di: http://dx.doi.org/10.1016/j.rmed.2009.07. 010

Bauman RW. 2012. Microbiology : with Disease by Body System. 692-693 p.

Belardinelli JM. 2013. Recycling and refurbishing old antitubercular drugs : the encouraging case of inhibitors of mycolic acid biosynthesis.

Brown AK, Papaemmanouil A, Bhowruth V, Bhatt A, Dover LG, Besra GS. 2017. Flavonoid inhibitors as novel antimycobacterial agents targeting Rv0636, a putative dehydratase enzyme involved in Mycobacterium tuberculosis fatty acid synthase II. (2007):3314-22.

Cantaloube S, Veyron-churlet R, Haddache N, Daffe M. 2011. The Mycobacterium Tuberculosis FAS-II Dehydratases and Methyltransferases Define the Specificity of the Mycolic Acid Elongation Complexes. 6(12). 
Chan ES, Yim ZH, Phan SH, Mansa RF, Ravindra P. 2010. Encapsulation of herbal aqueous extract through absorption with ca-alginate hydrogel beads. Food Bioprod Process, 88:195201.

De S, Robinson D. 2003. Polymer relationships during preparation of chitosan-alginate and polyl-lysine-alginate nanospheres. $J$ Control Release, 89(1):101-12.

Ding P, Li X, Jia Z, Lu Z. 2017. Multidrugresistant tuberculosis ( MDR-TB ) disease burden in China: a systematic review and spatio-temporal analysis. BMC Infect Dis [Internet]. BMC Infectious Diseases, 1-30. Tersedia di: http://dx.doi.org/10.1186/s12879-0162151-5

Dong Y, Qiu X, Shaw N, Xu Y, Sun Y, Li X, et al. 2015. Molecular basis for the inhibition of $\beta$-hydroxyacyl-ACP dehydratase HadAB complex from Mycobacterium tuberculosis by $\mathrm{fl}$ avonoid inhibitors. Protein Cell. Higher Education Press, 6(7):504-17.

Dustgani A, Farahani E, Imani M. 2008. Preparation of Chitosan Nanoparticles Loaded by Dexamethasone Sodium Phospate. Iran J Pharm Sci, 4(2):111-4.

Europe E. 2008. Multidrug resistant to extensively drug resistant tuberculosis: What is next ?. 33(November):605-16.

Faso B, Africa W, Mourfou A, Oue F, Sawadogo I. 2009. Risk Factors for Multidrug-Resistant Tuberculosis. 15(3).

Garg T, Goutam R, Amit KG. 2015. Inhalable chitosan nanoparticles as antitubercular drug carriers for an effective treatment of tuberculosis. Artif Cells, Nanomedicine, Biotechnol, 1-5.

Ginsberg AM. 2010. Drugs in Development for Tuberculosis.70(17):2201-14.

Gupta R, Thakur B, Singh P, Singh HB, Sharma VD, Katoch VM. 2010. Anti-tuberculosis activity of selected medicinal plants against multi- drug resistant
Mycobacterium tuberculosis isolates. 809-13.

Honary S, Maleki M, Karami M. 2009. The Effect of Chitosan Molecular Weighton the Pro-perties of Alginate/Chitosan Microparticles Containing Prendisolone. Trop J Pharm Res, 8(1):53-61.

Ikram S, Ahmed S. 2017. Natural Polymers. Hauppauge Nov Sci Publ Inc.

Iswanda R, Anwa E, Jufri M. 2013. Formulasi Nanopartikel Verapamil Hidroklorida dari Kitosan dan Natrium Tripolifosfat dengan Metode Gelasi Ionik. J Farm Indones, 6(4).

Jain P, Hossain KR, Mishu TR, Reza HM. (2014). Antioxidant and Antibacterial Activities of Spondias pinnata Kurz . Leaves. 4(2):183-95.

Jeon D, Jeong M, Jnawali HN, Kwak C, Ryoo S, Jung ID, et al. 2017. Phloretin Exerts Anti-Tuberculosis Activity and Suppresses Lung Inflammation.

Jim A, Meckes M, Torres J, Luna-herrera J. 2007. Antimycobacterial triterpenoids from Lantana hispida ( Verbenaceae ). 111:202-5.

Jiménez-Arellanes A, Meckes $\mathrm{M}$, Torres $\mathrm{J}$, Luna-Herrera J. 2007. Antimycobacterial triterpenoids from Lantana hispida (Verbenaceae). J Ethnopharmacol. 111(2):202-5.

Kunwar RM, Shrestha KP, Bussmann RW. 2010. Traditional herbal medicine in Farwest Nepal : a pharmacological appraisal. J Ethnobiol Ethnomed [Internet]. BioMed Central Ltd, 6(1):35. Tersedia di: http://www.ethnobiomed.com/content/6/ $1 / 35$

Labu Z, Laboni F, Tarafdar M, Howlader M, Rashid M. 2015. Membrane Stabilization as a Mechanism of Antiinflammatory and Thrombolytic Activities of Ethanolic Extract of Aerial Parts of Spondias Pinnata (Family:Anacardiaceae).2:4451.

Lee S, Koo H, Jeong H, Huh M, Choi Y, Jeong 
S, et al. 2011. Comparative study of photosensitizer loaded and conjugated glycol chitosan nanoparticles for cancer therapy. J Control release, 152(1):9-21.

Lin Y. 2014. Seasonal dynamics of tuberculosis epidemics and implications for multidrug-resistant infection risk assessment. 358-70.

Liu Z, Jiao Y, Wang Y, Zhou C, Zhang Z. 2008. Polysaccharides-Based Nanoparticles as Drug Delivery Systems. Adv Drug Deliv Rev, 60:1650-62.

Long R, Langlois-klassen D. 2013. Increase in Multidrug-resistant Tuberculosis (MDRTB) in Alberta Among Foreign-born Persons: Implications for Tuberculosis Management. 104(1).

López-garcía S, Castañeda-sanchez JI, Jiménezarellanes A, Domínguez-lópez L, Castromussot ME, Hernández-sanchéz J, et al. 2015. Macrophage Activation by Ursolic and Oleanolic Acids during Mycobacterial Infection. 2:14348-64.

Lu X, Zhu T, Chen C, Liu Y. 2014. Right or Left: The Role of Nanoparticles in Pulmonary Diseases. 17577-600.

Macedo R, Fernandes E, Brum L. 2008. Multidrug-Resistant Tuberculosis in Lisbon, Portugal : 14(2).

Mag P, Chaudhuri D, Ghate NB, Singh SS, Mandal N. 2015. Methyl gallate isolated from Spondias pinnata exhibits anticancer activity against human glioblastoma by induction of apoptosis and sustained extracellular signal regulated kinase $1 / 2$ activation. 11(42).

Morgen M, Bloom C, Beyerinck R, Bello A, Song W, Wilkinson K, et al. 2012. Polymeric Nanoparticles for Increased Oral Bioavailability and Rapid Absorption Using Celecoxib as a Model of a Low- Solubility, High-Permeability Drug. 427-40.

Nasiruddin M, Neyaz M, Das S. 2017. Nanotechnology-Based Approach in
Tuberculosis Treatment. Tuberculosis research and treatment.

Ngo D, Vo T, Ngo D, Kang K, Je J, Pham H, et al. 2014. Biological effects of chitosan and its derivatives. Food Hydrocoll, 51:200-16.

Olugbuyiro JAO, Moody JO, Hamann MT. 2009. AntiMtb activity of triterpenoidrich fractions from Spondias mombin L . 8(9):1807-9.

Purwani S, Ariantari N, Kardena I. 2013. Pengaruh Pemberian Ekstrak Etanol 80\% Daun Kedondong Hutan Terhadap Berat Organ Hati Mencit Jantan Galur Balb/c. $J$ udayana. 2(3).

Rudzinski WE, Aminabhavi TM. 2010. Chitosan as a carrier for targeted delivery. Int J Pharm, (399):1-11.

Savitri L, Ariantari N. 2013. Potensi Antituberkulosis Ekstrak n-heksana Daun Kedondong Hutan (Spondias pinnata (Lf) Kurz.). Jurnal Farm Udayana, 2(3).

Silva D, Araújo AR, Al. E. 2012. Chemical composition, antioxidant and antibacterial activities of two Spondias species from Northeastern Brazil. Pharm Biol, 50(6):740-6.

Skrahina A, Hurevich H, Zalutskaya A, Sahalchyk E, Astrauko A, Hoffner S, et al. 2013. Multidrug-resistant tuberculosis in Belarus : the size of the problem and associated risk factors. (October 2012):36-45.

Sosnik A, Carcaboso AM, A.M Glisoni R., Moretton M., Chiappetta D. 2010. New old challenges in tuberculosis: potentially effective nanotechnologies in drug delivery. Adv Drug Deliv Rev, 62:54759.

Srivastava K, Satyanarayana S. 2007. Poverty, health \& intellectual property rights with special reference to India. Indian $\mathrm{J}$ Med Res, 126(4):390-406.

Trisnawati NR, W PAS, Sugitha IM. 2011. Daya Hambat Ekstrak Daun Cemcem 
(Spondias pinnata(L.f)Kurz) terhadap Pertumbuhan. Escherichia coli ATCC 8739 secara In Vitro.

Uddin J, Islam N, Ali H, Khan SA, Labu ZK. 2016. Correlation of Thrombolytic and Membrane Stabilizing Activities with Total Flavonoid Content Aerial Parts of Spondias pinnata. 19(1):48-52.

Vandamme TF, Poncelet D, Subra-Paternault P. 2007. Microencapsulation: des sciences auxtechnologies. Lavoisier Tec Doc Paris, Fr.

World Health Organization (WHO). 2015. Global Tuberculosis Report 2015.

Zhang X. 2008. Substrate Recognition by Bacterial Enoyl Reductases from Escherichia coli and Mycobacterium tuberculosis.

Zhang X, Yang X, Ji J, Liu A, Zhai G. 2016. Tumor targeting strategies for chitosanbased nanoparticles. Colloids Surfaces B Biointerfaces, 148:460-73.

Zheng Y, Jiang X, Gao F, Song J, Sun J, Wang $\mathrm{L}$, et al. 2014. Identification of plantderived natural products as potential inhibitors of the Mycobacterium tuberculosis proteasome. 14(1):1-7. 